\title{
The role of fibroblast growth factors and their receptors in prostate cancer
}

\author{
B Kwabi-Addo, M Ozen and M Ittmann
}

Department of Pathology, Baylor College of Medicine and Michael E DeBakey Department of Veterans Affairs Medical Center, Houston, Texas 77030, USA

(Requests for offprints should be addressed to M Ittmann, Research Service, Michael E DeBakey VAMC, 2002 Holcombe Blvd, Houston, Texas 77030, USA; Email: mittmann@bcm.tmc.edu)

\begin{abstract}
Prostate cancer is the most common malignancy in men in the USA and the second leading cause of cancer deaths. Fibroblast growth factors (FGFs), including FGF1 (acidic FGF), FGF2 (basic FGF), FGF6 and FGF8 are all expressed at increased levels in prostate cancer as paracrine and/or autocrine growth factors for the prostate cancer cells. In addition, increased mobilization of FGFs from the extracellular matrix in cancer tissues can increase the availability of FGFs to cancer cells. Prostate cancer epithelial cells express all four types of FGF receptors (FGFR-1 to -4) at variable frequencies. Expression of FGFR-1 and FGFR-4 is most closely linked to prostate cancer progression, while the role of FGFR-2 remains controversial. Activation of FGF receptors can activate multiple signal transduction pathways including the phospholipase $\mathrm{C} \gamma$, phosphatidyl inositol 3-kinase, mitogenactivated protein kinase and signal transducers and activators of transcription (STAT) pathways, all of which play a role in prostate cancer progression. Sprouty proteins can negatively regulate FGF signal transduction, potentially limiting the impact of FGF signaling in prostate cancer, but in a significant fraction of prostate cancers there is decreased expression of Sprouty $1 \mathrm{mRNA}$ and protein. The effects of increased FGF receptor signaling are wide ranging and involve both the cancer cells and surrounding stroma, including the vasculature. The net result of increased FGF signaling includes enhanced proliferation, resistance to cell death, increased motility and invasiveness, increased angiogenesis, enhanced metastasis, resistance to chemotherapy and radiation and androgen independence, all of which can enhance tumor progression and clinical aggressiveness. For this reason, the FGF signaling system it is an attractive therapeutic target, particularly since therapies targeting FGF receptors and/or FGF signaling can affect both the tumor cells directly and tumor angiogenesis. A number of approaches that could target FGF receptors and/or FGF receptor signaling in prostate cancer are currently being developed.
\end{abstract}

Endocrine-Related Cancer (2004) 11 709-724

\section{Introduction}

Prostate cancer is the most common visceral malignancy in men in the USA and the second leading cause of cancer deaths in this population. There is a large body of literature linking alterations of the fibroblast growth factor (FGF) system to initiation and progression of a wide variety of malignancies, including prostate cancer. There have been a number of excellent reviews of both the biology of FGFs and FGF receptors (Basilico \& Moscatelli 1992, Johnson \& Williams 1993, Dow \& deVere White 2000, Powers et al. 2000, Ornitz \& Itoh 2001) and their role in neoplastic transformation (Cronauer et al. 2003, Munro \& Knowles 2003). This review will therefore focus more narrowly on the role of FGFs and their receptors in normal prostate and prostate cancer since there is an extensive and growing literature in this area.

\section{The FGF signaling system}

The human FGF gene family consists of at least 23 different genes encoding related polypeptides. FGFs are expressed in almost all tissues and play important roles in a variety of normal and pathological processes, including development, wound healing and neoplastic transformation. The FGFs are mitogenic for many cell types, both epithelial and mesenchymal. Some FGFs, like FGF2, 
have potent angiogenic activity and have been implicated as promoters of tumor angiogenesis. FGFs have also been shown to increase the motility and invasiveness of a variety of cell types. Finally, it has been shown that FGFs can inhibit cell death in the appropriate context. Thus FGFs have a broad range of biological activities that can play an important role in tumorigenesis.

FGFs interact with a family of four distinct, highaffinity tyrosine kinase receptors, designated FGFR-1 to -4 (Johnson \& Williams 1993). The receptors consist of an extracellular portion containing three immunoglobulinlike domains and an intracellular tyrosine kinase domain and have variable affinities for the different FGFs. In addition, FGFRs-1 to -3 all undergo an alternative splicing event in which two alternative exons (IIIb and IIIc) can be used to encode the carboxy terminal portion of the third immunoglobulin-like loop, which results in receptor isoforms with dramatically altered binding specificity. The IIIa alternatively spliced isoform is secreted. A variety of other alternative splicing events have been described, including alternative splicing that results in loss of the first extracellular immunoglobulin-like domain.

The third component of the FGF system is extracellular matrix (ECM) and secreted proteins that help mobilize FGFs from the ECM. Heparin and heparin sulfate proteoglycans play a critical role in facilitating FGF signaling via FGF receptors, although there is controversy regarding the exact manner by which this occurs (Powers et al. 2000). FGFs are bound in the extracellular matrix and can be released by the activity of degradative enzymes such as proteases. In addition, FGFbinding protein (FGF-BP), a $17 \mathrm{kDa}$ secreted polypeptide, can reversibly bind FGF1 and FGF2 and can facilitate release of FGFs from the extracellular matrix and interaction of these growth factors with cellular receptors (Aigner et al. 2001).

Binding of FGFs to the extracellular domains of FGF receptors results in receptor dimerization and transphosphorylation of tyrosine residues in the intracellular domain that is required for FGF receptor kinase activation. Ultimately, activation of FGF receptors leads to signal transduction through multiple pathways including phospholipase C $\gamma$ (PLC $\gamma$ ) (Burgess et al. 1990, Mohammadi et al. 1991), phosphatidylinositol 3-kinase (PI3K) (Hart et al. 2001), mitogen-activated protein kinases (MAPK) (Hadari et al. 2001) and signal transducers and activators of transcription (STATs) (Hart et al. 2000, Deo et al. 2002, Udayakumar et al. 2002). These effectors in turn disseminate the receptor tyrosine kinase signals by activating many target proteins, including transcription factors in the nucleus (Fig. 1). All of these pathways have been shown to be upregulated in prostate cancer and there is strong evidence linking each of these pathways to prostate cancer initiation and progression.

The docking proteins, FRS $2 \alpha$ and FRS2 $\beta$, play a critical role in mediating the intracellular signals that are generated at the cell surface by activation of the FGF receptors. Both FRS $2 \alpha$ and FRS $2 \beta$ contain myristyl anchors and phosphotyrosine-binding sites in their Cterminal tails that serve as binding sites for the adaptor protein, Grb2, and for the Src homology (SH) 2 domain containing protein tyrosine phosphatase, Shp2 (Kouhara et al. 1997, Hadari et al. 1998). In response to FGF stimulation, Grb2 can also be recruited indirectly to FRS $2 \alpha$ through its interaction with tyrosine-phosphorylated Shp2 molecules bound to the docking protein (Hadari et al. 1998). FGF-induced tyrosine phosphorylation of FRS2 $\alpha$ results in complex formation with the adaptor protein Grb2 bound to $\mathrm{Cbl}$ by means of its $\mathrm{SH} 3$ domains. FGF-induced ternary complex formation among FRS2 $\alpha$, Grb2 and $\mathrm{Cbl}$ results in ubiquitination and degradation of FRS $2 \alpha$ and FGF receptor (Wong et al. 2002). Thus, FRS $2 \alpha$ functions as a central platform for recruitment of multiprotein complexes that are responsible for both signal activation and attenuation.

A new family of regulators of FGF activity has recently been identified. Sprouty inhibits signaling mediated by the FGF receptor and the epidermal growth factor (EGF) receptor during eye development and oogenesis in Drosophila (Casci et al. 1999, Kramer et al. 1999, Reich et al. 1999). Four mammalian genes (Sprouty 1-4) have been identified with sequence similarity to Drosophila Sprouty (Tefft et al. 1999). In vitro studies have demonstrated that after growth factor stimulation, Sprouty1 and Sprouty2 translocate to the plasma membrane, become tyrosine phosphorylated, and interact with components of the Ras/MAPK and Ras/Raf/ERK pathways and other proteins including c-Cb1, Grb2, Raf1, FRS2, Caveolin-1, dual specificity kinase TESK1, the protein tyrosine phosphatase PTP1B and the Drosophila Ras-GAP, Gap1 (Dikic \& Giordano 2003) but the precise molecular mechanism by which the FGF receptor signal is blocked remains controversial.

\section{FGFs and FGF receptors in normal prostate}

The prostate is a mixed epithelial and stromal organ that requires androgenic stimulation for its development, maintenance and growth. There is a considerable body of evidence indicating that interaction between the stroma and epithelium plays a crucial role in the growth and development of the prostate. The mesenchymal elements in the prostate appear to mediate the development of this organ in response to androgens (Chung et al. 1991, 


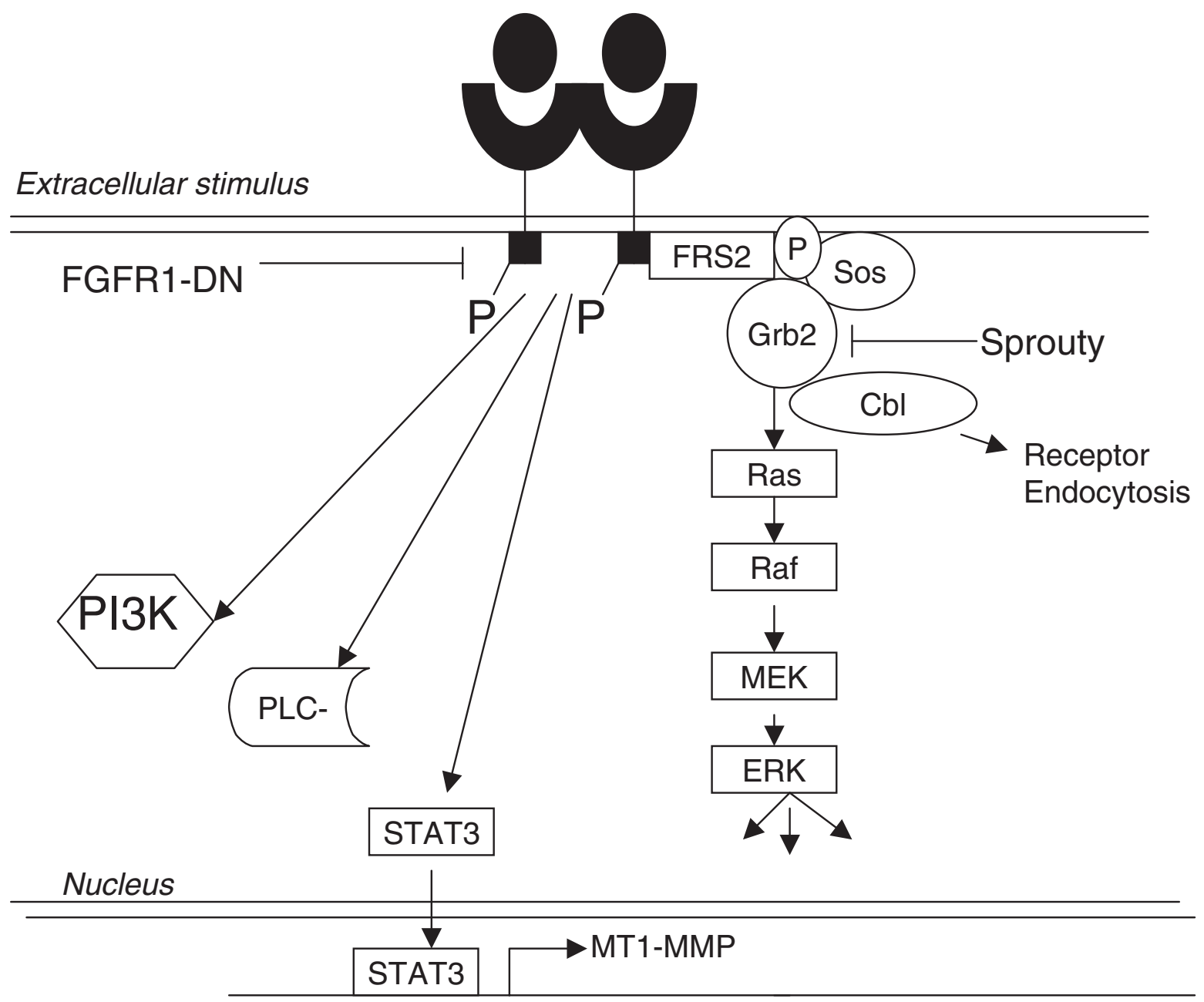

Figure 1 FGF signaling pathways in the prostate. Ligand binding initiates receptor dimerization and activation, promoting binding of the adaptor molecule FRS2 and the subsequent recruitment of adapter proteins Grb2 and Son of sevenless (Sos) to the FGF receptor complex. Sos facilitates guanine nucleotide exchange to activate Ras, which stimulates the Raf-to-MEK (MAPK)-to-extracellular signal-related kinase (ERK). These effectors, in turn, disseminate the receptor tyrosine kinase signals by phosphorylating many target proteins, including transcription factors in the nucleus. The PI3K, PLC $\gamma$ and STAT pathways are also activated by FGF receptor signaling. Regulators of FGF signaling include Sprouty. Cbl mediates downregulation of receptor protein. FGF receptor dominant negative (DN) proteins can be used to block FGF receptor signaling experimentally. MT1-MMP, membrane-type-I matrix metalloproteinase; $\mathrm{P}$ indicates phosphorylation.

Hayward et al. 1997). In addition, it has been shown that prostatic stromal cells in culture secrete factors into their medium that stimulate or inhibit prostatic epithelial growth in a paracrine manner (Kabalin et al. 1989, Yan et al. 1992). Thus the accepted paradigm is that in vivo the stromal cells secrete paracrine factors, some of which are under the control of androgens, which are responsible for the maintenance and growth of the epithelium. The major source of FGFs in human prostate is the prostatic stromal cells and they can act as paracrine growth factors for the epithelial cells. FGF2 (basic FGF), FGF7 (KGF) and FGF9 are expressed by the stromal cells of the prostate in biologically significant quantities. The mean FGF2 content of normal peripheral zone tissue as measured by ELISA is $110 \mathrm{ng} / \mathrm{g}$ wet weight (Giri et al. 1999a). FGF2 does not contain a classical signal peptide and is not efficiently secreted (Basilico \& Moscatelli 1992). Traditionally, it was thought that FGF2 is released by cellular damage. However, a number of investigations have indicated that FGF2 is actively (but inefficiently) secreted and recent evidence indicates that FGF2 can be actively transported across the plasma membrane (Schafer et al. 2004) and/or can be released by extracellular vesicle shedding (Taverna et al. 2003). FGF7 is present at approximately $28 \mathrm{ng} / \mathrm{g}$ wet weight in normal prostate (Giri et al. 1999a). FGF7 contains a classic signal peptide 
and is actively secreted. It has been reported that FGF7 is induced by androgens in cultures of rat (Yan et al. 1992) and human (Planz et al. 1998) prostatic stromal cells, but observations on castrated rats indicated that FGF7 expression in the prostate may not be androgen regulated in vivo (Nemeth et al. 1998) so the effect of androgens on FGF7 production is controversial. Our laboratory has shown a small increase in FGF7 secretion in organ cultures of normal prostate tissue in response to androgens (authors' unpublished data), supporting the idea that FGF7 expression by stromal cells can be regulated at least partially by androgens, but other factors may be more important (Giri \& Ittmann 2000). We have also found that FGF9 is expressed by prostatic stromal cells and is present in normal prostate tissue at approximately $51 \mathrm{ng} / \mathrm{g}$ wet weight by ELISA (authors' unpublished data). FGF9 is actively secreted and acts as a growth factor for both prostatic epithelial and stromal cells in culture (Giri et al. 1999b). All of these FGFs are potent growth factors for primary epithelial cells in culture at $1-10 \mathrm{ng} / \mathrm{ml}$, so it is clear that the concentrations of FGFs present in normal prostate are biologically significant. FGF10 is expressed by stromal cells, but is present at low levels in normal adult prostate and probably does not act as a significant growth factor in this context, although it is important for prostatic development (Ropiquet et al. 2000a). In addition to these stromal FGFs, epithelial-derived FGFs are present in the normal prostate. Small amounts of FGF6 can be observed in basal cells of normal prostate gland (Ropiquet et al. 2000b) on immunohistochemistry (IHC). We have recently found that FGF17 is expressed in relatively small amounts by prostate epithelial cells (Polnaszek et al. 2004). Both of these FGFs are actively secreted and, given that they are expressed by the epithelial cells in an autocrine manner, they may have biological importance that is disproportionate to their relatively low expression level, since they would not have to diffuse across the ECM in order to interact with epithelial FGF receptors.

The expression of the other FGFs that we have evaluated to date in normal human prostate are substantially less than FGF2, FGF7 and FGF9. We have shown that expression of FGF1 (acidic FGF) is barely detectable by RT-PCR in normal prostate and in primary cultures of prostatic stromal cells, but cannot be detected by Northern blotting (Ittmann \& Mansukhani 1997). We have also detected FGF5 and FGF8 mRNA in human prostate by RT-PCR but neither of these was detectable by Northern blotting (Ittmann \& Mansukhani 1997). Our observations regarding the expression of FGF8 in normal human prostate are supported by similar observations by other laboratories (Ghosh et al. 1996). No expression of FGF3, FGF4 or FGF16 was detected by RT-PCR of normal peripheral zone tissue (Ittmann \& Mansukhani 1997, authors' unpublished observations). Expression of FGF15, FGF19 and FGF20-23 in normal prostate has not been examined to date, to our knowledge. FGFs 11-14 do not appear to be secreted and at least two of these FGF family members act as intracellular signal transduction scaffolding molecules rather than as growth factors (Schoorlemmer \& Goldfarb 2001). We have detected expression of FGF13 but not FGF14 in normal prostate by RT-PCR (authors' unpublished data).

Prostate epithelial cells express multiple FGF receptors. FGFR-1 and FGFR-2 are expressed in the basal epithelial cells of the prostate but not the luminal cells (Giri et al. 1999a). Based on studies of primary epithelial cells in culture, FGFR-1 is present exclusively as the IIIc isoform, while FGFR-2 is present exclusively as the IIIb (FGF7 specific) isoform in the epithelium (Ittmann \& Mansukhani 1997). FGFR-3 is also present in prostatic epithelium, predominantly, but not exclusively, as the IIIb isoform (Kwabi-Addo et al. 2001). Finally, FGFR-4 is also expressed in prostatic epithelium and IHC has revealed that it is expressed in the luminal epithelial cells (Wang et al. 2004b). Based on the known properties of the various FGF receptor isoforms (Ornitz et al. 1996), prostatic epithelial cells express appropriate receptors to respond to the FGFs present in normal prostate, i.e. FGFR-1 IIIc binds FGF2 and FGF6, FGFR-2 IIIb binds FGF7, FGFR-3 IIIb binds FGF9, and FGFR-4 binds FGF2, FGF6 and FGF9.

\section{Expression of FGFs in prostate cancer}

FGF1 (acidic FGF) is a potentially important mitogen in prostate cancer due to the fact that it is mitogenic when it binds any type and isoform of FGF receptor (Ornitz et al. 1996). More than $80 \%$ of prostate cancers express FGF1 in the cancer cells by IHC and that strong expression was correlated with increased Gleason score (Dorkin et al. 1999a). FGF1 was also increased in prostatic intraepithelial neoplasia (PIN). Both the PC3 and LNCaP prostate cancer cell lines express FGF1 (Payson et al. 1998). Expression of FGF1 is detected by RT-PCR (Foster et al. 1999) or Western blotting (Polnaszek et al. 2003) in a significant fraction of prostate cancer tissues in the TRAMP mouse model of prostate cancer. FGF1 has a nuclear localization motif and has been detected in the nucleus in other systems (Klingenberg et al. 2000) but the role of nuclear FGF1 in prostate cancer is unclear.

FGF2 (basic FGF) is expressed in many human malignancies, including prostate cancer. Using ELISA we have shown that FGF2 is present at significantly higher concentrations in clinically localized cancer tissue (almost 2.5-fold) when compared with normal prostate (Giri et al. 
1999a). Immunohistochemical analysis revealed that FGF2 was present in stromal cells within the prostate cancer, consistent with a paracrine effect of FGF2 in localized prostate cancer from radical prostatectomy specimens. We have also shown that prostate cancer expresses increased levels of interleukin-8 (IL-8) and that IL-8 can induce expression of FGF2 (Giri \& Ittmann 2001), so one candidate mediator for the induction of FGF2 expression in stromal cells is IL-8 secreted by the cancer cells. In contrast, two groups, using primarily tissues from more advanced cancers than our laboratory has analyzed, have examined expression of FGF2 in prostate cancer by IHC and detected expression of FGF2 in prostate cancer epithelial cells in the majority of these cases (Cronauer et al. 1997, Dorkin et al. 1999a). Most of the prostate cancers in these studies were locally advanced or metastatic and/or poorly differentiated and thus are much more aggressive than the cancers from the radical prostatectomy specimens studied by our group. High levels of expression of FGF2 are present in PC3 and DU145 prostate cancer cells (Cronauer et al. 1997) and both of these cell lines were derived from metastatic prostate cancer. In addition, it has been demonstrated that prostate cancer patients have elevated levels of serum FGF2 (Cronauer et al. 1997). Thus it seems likely that initially FGF2 is expressed as a paracrine factor by stromal cells in localized prostate cancer and during tumor progression there is a switch to autocrine expression. In support of this hypothesis, there is increased expression of FGF2 during progression of TRAMP prostate cancers to a poorly differentiated phenotype (Huss et al. 2003). When TRAMP mice were crossed with FGF2 knockout mice, there was a significant increase in survival and decreased metastasis in mice bearing even one FGF2 knockout allele, which supports the hypothesis that the increased FGF2 expression seen during progression in the TRAMP model is biologically important in tumor progression (Polnaszek et al. 2003). One interesting aspect of FGF2 biology is the production of high molecular weight forms of FGF2 (22 and $25 \mathrm{kDa}$ ) that arise from alternative translation initiation from $\mathrm{CUG}$ codons that preferentially localize directly to the nucleus and can promote growth in low serum in some cell types (Arese et al. 1999). These higher molecular weight forms are present in TRAMP prostate cancers (Huss et al. 2003). If FGF2 is expressed as autocrine growth factors by the cancer cells, these higher molecular weight intranuclear forms may be biologically significant.

Our laboratory has demonstrated that FGF6 is increased in prostate cancer (Ropiquet et al. 2000b) and high grade PIN. ELISA of tissue extracts of normal prostate, PIN and prostate cancer for FGF6 showed that this growth factor was undetectable in normal prostate but was present at elevated levels in four of nine PIN lesions and in 15 of 24 prostate cancers. Immunohistochemical analysis with anti-FGF6 antibody revealed weak staining of prostatic basal cells in normal prostate that was markedly elevated in PIN. FGF6 may play a unique role in prostate cancer by acting as a paracrine factor secreted by residual basal cells in PIN that supports the growth of the dysplastic luminal epithelial cells. In the prostate cancers, IHC revealed autocrine expression of FGF6 by the prostate cancer cells in the majority of the cases.

The role of FGF7 in prostate cancer is unclear. We have measured expression of FGF7 in prostate cancer tissue from radical prostatectomy specimens by ELISA and have found that expression of FGF7 is similar in normal and cancer tissue and that, by IHC, as in normal tissue FGF7 is expressed by stromal cells (Giri et al. 1999a). We have recently confirmed that there is no increase in expression of FGF7 mRNA is prostate cancer tissue using quantitative RT-PCR (authors' unpublished data). In contrast, Planz et al. (1999) have reported expression of FGF7 in cancer cells on IHC of sections from radical prostatectomies using a different antibody. Serum FGF7 levels are lower in men with prostate cancer than in men with benign prostatic hyperplasia (BPH) (Mehta et al. 2000a), and we have shown that FGF7 is substantially elevated in BPH tissue (Ropiquet et al. $1999 b$ ), consistent with our observation that FGF7 is not elevated in prostate cancer. Further studies are needed to determine if there is increased expression of FGF7 in prostate cancer. In addition, as will be discussed below, it is unclear whether activation of FGFR-2, the only receptor that binds FGF7, promotes prostate cancer progression, so that even if FGF7 is increased it is not clear whether it would promote tumor progression.

Expression of FGF8 in human prostate cancer cells, both by in situ hybridization and IHC, has been well documented, while normal prostate expresses little detectable FGF8 (Leung et al. 1996, Tanaka et al. 1998, Dorkin et al. 1999a,b, Valve et al. 2001, West et al. 2001, Gnanapragasm et al. 2003). Overall, about 50\% of clinically localized cancers express increased FGF8 while $80 \%$ or more of advanced cancers express increased FGF8. Dorkin et al. (1999b) observed strong correlations of FGF8 expression with tumor grade, stage and patient survival, although FGF8 did not appear to be an independent predictor of survival on multivariate analysis. An interesting aspect of FGF8 is that its mRNA undergoes alternative splicing, yielding multiple isoforms designated FGF8a, b, e and $\mathrm{f}$ (Ghosh et al. 1996). FGF8b is apparently the major isoform expressed in prostate cancer, although expression of the other alternatively spliced isoforms has also been reported in prostate cancers (Valve et al. 2001). FGF8b is 
expressed by LNCaP, DU145 and PC3 cells and it has transforming activity in NIH3T3 cells (Tanaka et al. 1995, Ghosh et al. 1996). Increased expression of FGF8b in LNCaP cells using a lentivirus vector resulted in increased growth, colony formation in soft agar, invasion and tumorigenesis in vivo and facilitated growth-promoting stromal-epithelial interactions (Song et al. 2000a). Taking the opposite approach, Rudra-Ganguly et al. (1998) showed that antisense inhibition of FGF8 expression in DU145 cells decreased soft agar colony formation and tumorigenicity in vivo. Prostate-specific expression of FGF8b in transgenic mice under the control of an enhanced probasin promoter results in progressive epithelial hyperplasia and ultimately PIN, although invasive carcinoma was not reported (Song et al. 2002). Taken together, the finding of expression in human tissues that correlates with clinical and pathological parameters of aggressive disease and the biological observations in vitro and in vivo are convincing for the importance of FGF8 in human prostate cancer progression.

We have detected expression of FGF17 in normal prostatic epithelium and this expression is maintained in cancer cells (Polnaszek et al. 2004). Although, in samples from clinically localized cancers, the amount of FGF17 per cancer cell is similar to that in normal epithelial cells, the cancer cells constitute most of the tissue volume within the cancer tissue, leading to increased local FGF17 concentration. The FGF17 present in such cancers can act as an autocrine growth factor for the prostate cancer cells. We also observed increased expression of FGF17 in the DU145 cell line, suggesting that FGF17 may be expressed at increased levels in advanced prostate cancers. Further studies of FGF17 expression in advanced cancer tissues are needed to clarify this question.

In summary, multiple FGFs are expressed either as autocrine or paracrine growth factors in PIN and prostate cancer tissues. Many questions remain to be answered. Due to the fragmentary and relatively small scale of most the studies reported to date, the extent to which the expression of the different FGFs overlap is unclear, although Dorkin et al. (1999a) did examine FGF1, FGF2 and FGF8 by IHC in relatively advanced cancers and found that the expression of these growth factors was only partially overlapping. Expression of any one FGF has not been shown to be an independent prognostic factor on multivariate analysis, but the relatively small number of specimens involved in the published studies limits the power of this analysis and the possibility that the FGFs may act synergistically should be examined. The advent of tissue microarrays should greatly facilitate simultaneous analysis of multiple FGFs in large numbers of prostate cancers. In addition, not all FGFs have been studied quantitatively, so it is difficult to determine the relative expression levels of the different FGFs in cancer tissues. Finally, the most important question is the mechanism by which expression of FGFs is regulated in prostate cancer cells. FGF expression can be modulated by transcriptional, post-transcriptional and translational mechanisms, but little is known about what underlies the expression of FGFs as autocrine growth factors in prostate cancer cells. Although androgen may modulate expression of some FGFs, it seems unlikely that androgen receptor alone can selectively increase expression in cancer cells, since androgen receptor is also active in the benign cells. Further studies are needed to determine how FGF expression in upregulated in prostate cancer.

\section{Expression of FGF receptors in prostate cancer}

Our laboratory has shown that FGFR-1 is expressed in approximately $20 \%$ of moderately differentiated cancers and $40 \%$ of poorly differentiated clinically localized cancers based on IHC and Western blotting of prostate cancer extracts, but was not detected in well-differentiated cancers (Giri et al. 1999a). Prostate cancer cells most closely resemble prostatic luminal epithelial cells in their differentiation, in that they express cytokeratins that are similar to these cells and prostate-specific antegen (PSA). Given that luminal epithelial cells do not express FGFR-1, it appears that with transformation and progressive loss of differentiation, there is increasing expression of FGFR-1. Takahashi (1998) found increased expression of FGFR-1 mRNA in poorly differentiated prostate cancer, with which our results are consistent. Naimi et al. (2002) found relatively equal expression of FGFR-1 IIIc in normal prostate and cancer tissues by quantitative RT-PCR. However, FGFR-1 IIIc is expressed in stromal cells and as the cancer epithelial cells replace stroma in the cancer tissues (which were $90 \%$ cancer in this study), there would be a marked decrease in FGFR-1 IIIc unless the cancer epithelial cells express FGFR-1 IIIc. Thus, these quantitative RT-PCR results are also consistent with our IHC observations. FGFR-1 is also expressed preferentially in poorly differentiated TRAMP prostate cancers (Huss et al. 2003). In the Dunning rat prostate carcinoma model, FGFR-1 expression promotes tumor progression (Feng et al. 1997). Transgenic models that express constitutively active FGFR-1 in the prostate epithelium develop hyperplasia and PIN (Wang et al. 2002, 2004a) and increased expression accelerates the appearance of this phenotype (Jin et al. 2003). Transgenic mice in which FGFR-1 kinase is activated by a chemical dimerizer also develop PIN when treated with dimerizer drug (Freeman et al. 2003a). Finally, activation of FGFR-1 in TRAMP cell lines using chemical dimerizer enhanced tumor 
proliferation in vitro and in vivo (Freeman et al. 2003b). It should be noted that FGFR-1 IIIc binds FGF2 and FGF6, both of which are increased in prostate cancer tissues. Thus, all evidence to date strongly supports the hypothesis that FGFR-1 can promote prostate cancer progression.

In contrast to the consistent evidence linking FGFR-1 to prostate cancer progression, the role of FGFR-2 in prostate cancer is far less clear. Activation of FGFR2-2 IIIb by FGF7 can enhance proliferation of primary or immortalized prostate epithelial cells in vitro (Ropiquet et al. 1999a,b) and prostate-specific expression of FGF7 expression promotes hyperplasia of prostatic epithelium in a transgenic model in vivo (Foster et al. 2002). As described above, FGF7 is expressed in prostate cancer tissues at levels similar to those in normal prostate. However, McKeehan and his colleagues have shown that in the Dunning rat prostate cancer model FGFR-2 IIIb expression inhibits neoplastic progression (Feng et al. 1997, Matsubara et al. 1998). Furthermore, when FGFR-2 kinase is activated in a transgenic mouse prostate epithelium using a chemical dimerizer, mice do not develop PIN (Freeman et al. 2003a), while activation of FGFR-2 by chemical dimerizer in TRAMP cell lines does not enhance tumor proliferation as observed for FGFR-1 (Freeman et al. 2003b). Finally, decreased FGFR-2 activity enhances the progression to PIN in mice expressing activated FGFR-1 (Jin et al. 2003). Thus most in vivo studies have found that FGFR-2 either inhibits or does not promote prostate cancer initiation and progression. Another complication is that FGFR-2 is expressed in normal prostate epithelium as the IIIb isoform, which binds almost exclusively to FGF7 and FGF10. During progression in the Dunning model there is a change in alternative splicing of FGFR-2, with increased expression of the IIIc isoform (Yan et al. 1993). In the DU145 cell line and in one of three prostate cancer xenografts studied, there was predominant expression of the FGFR-2 IIIc isoform, suggesting that exon switching to the FGFR-2 IIIc isoform by changes in alternative splicing may occur in human cancers (Carstens et al. 1997). Using a PCR-based approach we found that such isoform switching occurs in a subset of clinically localized cancers in vivo (Kwabi-Addo et al. 2001). TRAMP prostate cancers express increasing amounts of FGFR-2 during progression to the poorly differentiated phenotype and express the IIIc isoform even at the PIN stage (Huss et al. 2003). Such isoform switching would allow FGFR-2 to be activated by FGF2, FGF6 and FGF9 in human cancer tissue. However, if FGFR-2 activation does not promote or even inhibits tumor progression, it is difficult to see any selective advantage to the tumor cells in this isoform switching, unless the FGFR-2 IIIc is forming heterodimers with other FGF receptors such as FGFR-1 and activating them to promote cancer progression. It is also possible that such isoform switching is a manifestation of an epithelial to mesenchymal transition and does not in itself yield a selective advantage for tumor cells. Our laboratory has shown that FGFR-2 is expressed in approximately $30 \%$ of clinically localized cancers by IHC (Giri et al. 1999a). By quantitative RT-PCR, Naimi et al. (2002) found a decreased mean expression of both FGFR-2 IIIb and IIIc in prostate cancer tissues. However, if $70 \%$ of cancers do not express FGFR-2 and the cancer tissue is replacing normal epithelium and stroma (which expresses FGFR-2 IIIb and IIIc), one might expect a marked decrease in average FGFR-2 mRNA expression and this might not be compensated for by the $30 \%$ of cancers that do express FGFR-2, particularly if they express relatively low levels of the FGFR-2 mRNA. Further investigations are necessary to establish the role of FGFR-2 in prostate cancer, bearing in mind that it is possible that human prostate cancer may be heterogeneous in its response to FGFR-2 activation depending on the presence of other genetic alterations. A major goal is to understand the underlying differences in signal transduction between FGFR-1 and FGFR-2 that could lead to enhancement or inhibition of tumor progression by these two related receptors. In this regard, Freeman et al. (2003b) have shown that FGFR-1 but not FGFR-2 activation can induce osteopontin, which is known to facilitate tumor growth, although the basis for this difference in expression is still unclear.

FGFR-3 is expressed in normal prostate epithelium predominantly as the IIIb isoform and, based on PCR studies, it continues to be expressed in prostate cancer tissues predominantly as the IIIB isoform (Kwabi-Addo et al. 2001), which will bind FGF1 and FGF9. To date no immunohistochemical studies of FGFR-3 expression in prostate cancer have been reported. Using ELISA we have found that cancer tissues contain FGF9 at levels similar to normal prostate. Thus, FGFR-3 may have a role in FGF signaling in prostate cancer.

FGFR-4 is expressed in normal human prostate, in prostate cancer cell lines and in the immortalized human prostate epithelial cell line PNT1A by RT-PCR (KwabiAddo et al. 2001). Of note is the observation that FGF2, FGF6, FGF8 and FGF17, which are all present in human prostate cancer tissues, are potent activators of FGFR-4 (Ornitz et al. 1996). We have recently reported that FGFR-4 is expressed in luminal epithelial cells, PIN and in all of the prostate cancers examined (Wang et al. 2004b). A germline polymorphism in the FGFR-4 gene, resulting in expression of FGFR-4 containing either glycine $\left(\mathrm{Gly}^{388}\right)$ or arginine $\left(\mathrm{Arg}^{388}\right)$ at codon 388 has been identified and the presence of the FGFR-4 Arg388 allele is associated with decreased disease-free survival in breast cancer patients with lymph node metastasis as well 
as with metastasis and poor prognosis in colon cancer (Bange et al. 2002). We have found that the presence of homozygosity for the FGFR-4 $\mathrm{Arg}^{388}$ allele is significantly associated with prostate cancer incidence. In addition, the presence of the FGFR-4 Arg ${ }^{388}$ polymorphism is correlated with the occurrence of pelvic lymph node metastasis and PSA recurrence in men undergoing radical prostatectomy. Expression of the FGFR-4 $\mathrm{Arg}^{388}$ in immortalized prostate epithelial cells results in increased cell motility and invasion and upregulation of the urokinase-type plasminogen activator receptor, which is known to promote invasion and metastasis (Sidenius \& Blasi 2003). This may explain, in part, the increased aggressiveness of prostate cancers in men bearing this polymorphism. These findings indicate that FGFR-4 plays a significant role in prostate cancer initiation and progression.

There are several known mutations that activate FGF receptor signaling and play a role in genetic disorders of bone formation (Naski \& Ornitz 1998). Mutations of FGFR-3 that are associated with thantophoric dysplasia have been found to occur in a significant fraction of bladder cancers (Cappellen et al. 1999). However, these mutations do not occur in prostate cancers (Naimi et al. 2000, Sibley et al. 2001). A similar activating mutation in FGFR-2 also does not occur in prostate cancer (Mehta et al. 2000b). In addition to point mutations, fusion transcripts can lead to aberrant activity and fusions involving FGF receptor genes have been detected in hematopoietic malignancies (Xiao et al. 1998, Demiroglu et al. 2001, Li et al. 2001, Grand et al. 2004, Roumiantsev et al. 2004). Although such fusion transcripts have not been reported in prostate cancer, they may be quite hard to detect in a solid malignancy in which the cancer cells are difficult to grow in culture. Thus the major alteration that has been observed to date in FGF receptors during prostate cancer progression is increased expression.

Many questions remain regarding the role of FGF receptors in prostate cancer. As described above, the role of FGFR-2 and changes in alternative splicing of this receptor in prostate cancer progression are still not clear. The different FGF receptors display differences in signaling and biological activities in various systems, but whether these differences are fundamentally quantitative or qualitative in nature is unclear. FGFR-1 appears to activate the MAPK pathway more robustly than other FGF receptors (Shaoul et al. 1995, Raffioni et al. 1999). FGFR-4, in particular, appears to activate MAPK weakly and yet it can promote proliferation. In addition, FGFR-4 is the only FGFR that can promote membrane ruffling when tranfected into COS-7 cells (Johnston et al. 1995). Such membrane ruffling is associated with changes in the actin cytoskeleton related to increased motility. Thus, FGFR-4 activation may be more important in altering motility or other properties when compared with similar stimulation by other FGFRs. Further work is needed to understand these differences in FGF receptor activities in the context of prostate cancer. In this regard, the chemical dimerizer system for FGF receptor activation used by Spencer and his colleagues is attractive (Freeman et al. 2003a,b), since multiple FGF receptors and FGFs are expressed in the prostate cancer cell lines examined to date, making clean analysis of the effects of any single receptor difficult using FGF ligands. Finally, the basis for increased expression of FGF receptors is not clear. If one considers that the differentiation displayed by prostate cancers is more luminal than basal, it is not surprising that FGFR-4 which is expressed in normal luminal cells is widely expressed in prostate cancer. In contrast, expression of FGFR-1 and FGFR-2 is normally in basal cells and tends to be increased in more advanced and poorly differentiated cancer, implying that additional genetic alterations are needed to increase expression of these receptors. The nature of these alterations is unknown. Amplification of FGFR-1 and FGFR-2 has been reported in advanced prostate cancers (Edwards et al. 2003) but the observed amplifications are relatively low level (less than two-fold). It is likely that other genetic alterations enhance expression of FGF receptors in cancer cells. For example, overexpression of cyclin D1 in fibroblastic cells leads to upregulation of FGFR-1 (Tashiro et al. 2003). Interestingly, translation of both FGF2 and cyclin D1 are enhanced by expression of eIF4e, a cap-binding protein that can regulate protein synthesis, which is overexpressed in prostate cancer. Thus eIF4e could potentially have synergistic effects on proliferation by increasing both FGF ligand and receptor (de Benedetti \& Harris 1999). Thus genetic alterations that are known to affect prostate cancer cells can affect FGF receptor expression but further work is needed to determine if there is a linkage of these alterations to changes in FGF receptor expression in prostate cancer.

\section{The extracellular matrix, proteoglycans and FGF activity in prostate cancer}

Heparin and heparin sulfate proteoglycans play a critical role in FGF signaling, but little is known of how these molecules are modulated during prostate cancer initiation and progression. Syndecan-1 is a heparin sulfate proteoglycan that can potentially modulate FGFR-1 activity. Immunohistochemical analysis has revealed overexpression of syndecan-1 in prostate cancer and such overexpression is associated with increased Gleason score, early recurrence and decreased survival (Zellweger et al. 2003). However, syndecan-1 can interact with both matrix proteins and a number of different growth factors so that 
it is unclear whether the effect of syndecan-1 on clinical outcome is mediated via its potential interactions with FGFs. FGFs are extensively bound in the extracellular matrix and a variety of degradative enzymes, particularly proteases, can release them from the ECM. Thus, one potential way in which proteases can enhance tumor progression is by local release of FGFs. FGF-BP can reversibly bind FGF1 and FGF2 and release them from the extracellular matrix (Aigner et al. 2001). PC3, DU145 and LNCaP prostate cancer cells all express FGF-BP. Using ribozymes to FGF-BP, Aigner et al. (2002) were able to demonstrate that decreased FGF-BP is associated with decreased proliferation and tumorigenicity in PC3 cells. Thus FGF-BP can significantly enhance the biological activities of FGFs. The extent to which FGF$\mathrm{BP}$ is expressed in clinical prostate cancer specimens has not been reported to date. Overall, how the ECM and factors releasing FGFs from the ECM contribute to FGF receptor activation modulation in prostate cancer is not well understood and warrants further investigation.

\section{Alterations of modulators of FGF signal transduction in prostate cancer}

As described above, members of the Sprouty gene family negatively regulate FGF signaling in a variety of systems and could potentially limit the biological activity of FGFs in prostate cancer. Recently Kwabi-Addo et al. (2004) have established that decreased Sprouty 1 expression may play a role in prostate cancer. Immunohistochemical analysis of normal and neoplastic prostate tissues using tissue microarrays revealed that Sproutyl protein is downregulated in approximately $40 \%$ of prostate cancers. By quantitative real-time PCR, Sprouty1 mRNA levels were significantly decreased in prostate cancers in vivo in comparison with normal prostate. In prostate cancer cell lines there was loss of the normal upregulation of Sprouty 1 mRNA in response to FGFs. The decrease in Sproutyl expression in the human prostate cancer, despite elevated levels of FGF ligands and FGF receptors, implies a loss of an important growth-regulatory mechanism in prostate cancers that may potentiate the effects of increased FGF and FGF receptor expression in prostate cancer. Alterations of expression of other Sprouty family members and other proteins that may regulate FGF signal transduction in prostate cancer are currently being investigated.

\section{Biological effects of FGFs and FGF receptors in prostate cancer}

As described above, there is extensive evidence that FGF receptor signaling is enhanced in prostate cancer by multiple mechanisms including increased expression of
FGF ligands and receptors, increased mobilization of FGFs from the ECM and loss of negative regulation of FGF signaling. This increased FGF receptor signaling results in activation of multiple signal transduction pathways. The effects of such increased FGF receptor signaling are wide ranging and involve both the cancer cells and surrounding stroma, particularly the vasculature. For prostate cancer, the biological consequences of increased FGF signaling include enhanced proliferation, resistance to cell death, increased motility and invasiveness, increased angiogenesis, enhanced metastasis, resistance to chemotherapy and radiation and androgen independence, all of which can enhance tumor progression and clinical aggressiveness.

Exogenous FGFs can promote proliferation of normal, immortalized and fully transformed prostatic epithelial cells. Our laboratory has shown that FGF2, FGF6, FGF7, FGF9 and FGF17 can all enhance normal and/or neoplastic prostatic epithelial cell proliferation. Song et al. (2000a) investigated the biological effects of overexpression of FGF8b in prostate cancer and demonstrated increased growth rate in comparison with controls. In addition, FGF-BP depletion reduces proliferation (Aigner et al. 2002). Activation of FGF signaling in vivo in multiple transgenic mouse models also leads to enhanced proliferation. Thus one major effect of FGF signaling in prostate cancer cells is to enhance cell proliferation.

It has been shown in different systems that FGFs can inhibit cell death in the appropriate context (Fox \& Shanley 1996, Fujiwara et al. 2003, Erez et al. 2004). Our laboratory has demonstrated that FGF receptor signaling may act to provide an important survival signal in prostate cancer cells. Adenovirus-mediated expression of dominant negative FGF receptors, which blocks FGF signaling, leads to an arrest in G2 in prostate cancer cells followed by cell death (Ozen et al. 2001). Primary cultures of epithelial cells show reduced growth after infection with adenovirus-expressing dominant negative FGF receptors but not increased cell death, suggesting that cancer cells are particularly dependent on FGF signaling. We have made similar observations in melanoma cells and primary melanocytes (Ozen et al. 2004). As prostate cancers progress, the amount of stroma decreases and the amount of epithelium increases, particularly as cancers develop Gleason patterns 4 and 5, in which large areas of fused, cribiform tumor or sheets of cells are seen, so that there is far less stroma per unit volume to provide stromal FGFs to the epithelial cells. If the cancer cells require FGF signaling for survival, there would be a strong selective pressure for the emergence of cells that have genetic or epigenetic alterations that enhance FGF signaling, and such changes are common in human prostate cancers, as 
described above. Based on these observations, disruption of FGF signaling is an attractive therapeutic target in prostate cancer.

FGFs have significant biological function as positive regulators of angiogenesis. FGF1 and FGF2 were among the first angiogenic factors to be identified (Folkman \& Shing 1992, Powers et al. 2000) and other FGFs can also have angiogenic activity. When FGF2 is expressed in prostate cancer cells and cancer stroma it can induce the formation of tumor vasculature. PC3M cells that express high levels of secreted FGF2 were more angiogenic when growing as solid tumors in nude mice in contrast to DU145 cells (Connolly \& Rose 1998). In high grade prostate cancers, production of thrombospondin-1, a major inhibitor of angiogenesis, is downregulated while that of stimulatory FGF2 and/or vascular endothelial growth factor (VEGF) rise, and this is associated with increased microvessel density (Doll et al. 2001). Sugamoto et al. (2001) reported similar correlations. It should be noted that the angiogenic factors VEGF and IL-8 are increased along with FGF2 in prostate cancer and can act synergistically to promote angiogenesis. Hypoxia can increase expression of all of these factors by prostatic stromal cells (Berger et al. 2003) and presumably in cancer cells as well, and hypoxia may be responsible, at least in part, for the increased expression of these three angiogenic factors in prostate cancer. Huss et al. (2003) studied the process of angiogenesis and the temporal and spatial expression of the FGF axis during prostate tumor progression in the TRAMP model. They have demonstrated that FGFR-1 IIIb is specifically expressed in new vasculature associated with prostate cancer but not in the vessels of normal mouse prostate. Such increased expression of FGFR-1 could potentiate the effect of increased FGF2 on the tumor vasculature.

Growth factors are key regulators of proliferative and migratory events and FGFs play a role in wound repair (Ortega et al. 1998), which is characterized by both cellular proliferation and migration. In response to FGF2, endothelial cells increase the activation and ligation of integrin $\alpha_{\mathrm{v}} \beta_{3}$ to facilitate cellular migration process through the ERK pathway (Eliceiri et al. 1998). MMPs are elevated in many types of cancer including prostate cancer (Basset et al. 1990, Matrisian et al. 1991, Pajouh et al. 1991) and are involved in the invasion and metastasis of prostate cancer. MMPs are a family of endopeptidases that require zinc for catalytic activity and are capable of digesting ECM and basement membrane components (Newell et al. 1994). Increased expression of MMPs in prostate cancer leads to proteolytic breakdown of the basement membrane and ECM structures leading to release of FGFs (Mack et al. 1993). Matrilysin, a matrix metalloproteinase, can degrade the extracellular proteins, including proteoglycans, fibronectin, entactin, laminin, gelatin and elastin (Wilson \& Matrisian 1996). Its expression has been shown in prostate cancer (Pajouh et al. 1991) and can enhance the invasiveness of the DU145 prostate cancer cell line (Knox et al. 1996, Powell et al. 1993). It has been demonstrated that overexpression of matrilysin in prostate cancer is partially due to the paracrine factors secreted from the surrounding stroma (Klein et al. 1999) and inhibition of FGF receptor signaling can inhibit promatrilysin expression along with PSA expression and tumor growth in LNCaP prostate cancer cells (Udayakumar et al. 2003). Thus it is possible that a positive feedback loop could be established in which FGFs promote activity of MMPs which, in turn, leads to increased availability of FGFs by release from the ECM. We have recently demonstrated that immortalized prostatic epithelial cells expressing the $\mathrm{Arg}^{388}$ form of FGFR-4 have enhanced migration, invasiveness and expression of urokinase-type plasminogen activator receptor (Wang et al. 2004b), which plays a key role in cell motility and invasiveness. Thus FGFs can play an important role in invasion and migration by enhancing the activity of multiple proteolytic systems.

Given the biological effects described above it is not surprising that FGFs can enhance metastasis in vivo. Highly metastatic variants of PC3 express higher levels of FGF2 (Greene et al. 1997). Our laboratory has recently demonstrated, by crossing TRAMP mice with FGF2 knockout mice, that inactivation of even one FGF2 allele is associated with decreased metastasis (Polnaszek et al. 2003). Other FGFs probably have a similar effect on metastasis although this has not been established experimentally to date.

FGF2 could affect the cytotoxicity of chemical and other non-physiological stresses inflicted upon the cell. This is particularly important for the interaction of cancer cells with chemotherapy drugs and other DNA-damaging agents, including radiation. Depending on the type of cells studied, the chemotherapeutic or DNA-damaging agent used and the method of exposure to FGF2, such treatment can be either protective or sensitizing. Song et al. (2000b) have shown that the chemoresistance in lung metastases is caused by acidic and basic FGFs (aFGF and bFGF) expressed in solid tumors. Subsequently the same group investigated the effect of FGF inhibitors on doxorubicin activity in human prostate PC3 tumors (Zhang et al. 2001). Addition of suramin (which can inhibit FGF receptor activation) to doxorubicin therapy significantly enhanced the anti-tumor effect, resulting in complete inhibition of tumor growth. The protective effects of FGFs can also involve endothelial cells. For example, FGF2 can increase survival of radiated endothelial cells, which could limit the effectiveness of radiation 
therapy in inhibiting tumor angiogenesis (Abdollahi et al. 2003). While further studies are needed, the evidence to date indicates that increased FGF expression could contribute to the resistance of many prostate cancers to radiation and/or chemotherapy.

Androgen receptor activity is critical for prostate cancer cell survival and androgen ablation plays an important role in the treatment of prostate cancer, particularly in men with advanced disease. Unfortunately androgen-independent prostate cancer almost always emerges following androgen ablation, limiting the effectiveness of this therapy. The vast majority of androgenindependent prostate cancers continue to express androgen receptor and androgen receptor target genes such as PSA, indicating that the emergence of androgen independence is usually due to genetic or epigenetic changes that allow for activation of androgen receptor at extremely low androgen levels. Such changes include amplification and overexpression of androgen receptor, mutations of androgen receptor, increased expression of androgen receptor coactivators and activation of androgen receptor transcription by growth factor signaling. Culig et al. (1994) originally demonstrated that FGF7, insulin-like growth factor-I and EGF activate androgen receptordependent transcription in prostate cancer cells. It is now clear that multiple growth factors and cytokines can activate androgen receptor-dependent transcription, but the mechanism by which this occurs is still unclear. One potential mechanism is through activation of androgen receptor coactivators by the MAPK pathway (Debes et al. 2003, Rowan et al. 2000) but further detailed mechanistic studies are needed to fully understand the crosstalk between FGF receptor signaling and androgen receptor activity. However, given the evidence that FGF receptor signaling is increased in advanced prostate cancer, it is possible that FGFs contribute significantly to androgen receptor activity in androgen-independent disease.

\section{FGF receptors and FGF receptor signaling as therapeutic targets in prostate cancer}

Tyrosine kinases have emerged as a major potential therapeutic target in cancer therapy. Imatinib, which inhibits the BCR-abl kinase and c-kit, is highly effective in the treatment of chronic myelogenous leukemia and malignant gastrointestinal stromal tumors. Similarly, Her2/neu is an important target in breast cancer therapy. As described above, expression of FGF receptors and increased FGF receptor signaling are ubiquitous in human prostate cancer. Furthermore, since FGF signaling enhances multiple biological processes that promote tumor progression, most critically cell survival, it is an attractive therapeutic target, particularly since therapies targeting FGF receptors and/or FGF signaling can affect both the tumor cells directly and tumor angiogenesis. There are numerous approaches that could target FGF receptors and/or FGF receptor signaling in prostate cancer. One approach is to target cancer cells by conjugating FGF ligands to toxins (Davol \& Frackelton 1999) or adenoviruses carrying toxic genes (Lanciotti et al. 2003). Another approach would be to develop antibodies targeting FGF receptors that could either directly inhibit their activity or be used to target therapeutic molecules to the cancer cells and tumor vasculature. He et al. (2003) have used an interesting approach in which FGF receptor from a non-mammalian species (Xenopus) was used as a vaccine in mice and which led to inhibition of tumor growth. Finally, small molecule inhibitors of FGF signaling are under active development. SU5402 is a specific inhibitor of FGFR activity (Mohammadi et al. 1997). It has been shown to specifically inhibit the growth of chronic myeloid leukemia cell lines bearing an unusual translocation that results in the production of a BCRFGFR1 fusion protein (Demiroglu et al. 2001) as well as multiple myeloma cells bearing a rearrangement of FGFR-3 (Grand et al. 2004). In LNCaP cells, low doses of SU5402 have been shown to inhibit secretion of promatrilysin (Klein et al. 1999). Another FGF receptor inhibitor, PD173074, shows activity against breast cancer cell lines (Koziczak et al. 2004) and multiple myeloma cells expressing FGFR-3 fusion protein (Grand et al. 2004) and has anti-angiogenic activities in vivo (Dimitroff et al. 1999). SU5416 and SU668 are broad-spectrum antiangiogenic tyrosine kinase inhibitors that inhibit FGF receptors as well as VEGF and platelet-derived growth factor receptors and have anti-tumor effects in vivo (Griffin et al. 2002). These two agents are currently undergoing clinical trials for treatment of a variety of malignancies, although SU5416 has recently been reported not to be effective in advanced prostate cancer (Stadler et al. 2004). Finally, it should be noted that a number of chemotherapeutic agents such pegylated interferon- $\alpha-2 b$ (Huang et al. 2002) and taxanes (Cassinelli et al. 2002) downregulate expression of FGF2 and this may be part of their therapeutic effectiveness. While this effort is only beginning, agents targeting the FGF signaling system in prostate cancer may have therapeutic effectiveness and may well be integrated into patient treatment in the future.

\section{References}

Abdollahi A, Lipson KE, Han X, Krempien R, Trinh T, Weber KJ, Hahnfeldt P, Hlatky L, Debus J, Howlett AR \& Huber PE 2003 SU5416 and SU6668 attenuate the angiogenic effects of radiation-induced tumor cell growth factor production and 
amplify the direct anti-endothelial action of radiation in vitro. Cancer Research 63 3755-3763.

Aigner A, Butscheid M, Kunkel P, Krause E, Lamszus K, Wellstein A \& Czubayko F 2001 An FGF-binding protein (FGF-BP) exerts its biological function by parallel paracrine stimulation of tumor cell and endothelial cell proliferation through FGF-2 release. International Journal of Cancer 92 510-517.

Aigner A, Renneberg H, Bojunga J, Apel J, Nelson PS \& Czubayko F 2002 Ribozyme-targeting of a secreted FGFbinding protein (FGF-BP) inhibits proliferation of prostate cancer cells in vitro and in vivo. Oncogene 21 5733-5742.

Arese M, Chen Y, Florkiewicz RZ, Gualandris A, Shen b \& Rifkin DB 1999 Nuclear activities of basic fibroblast growth factor: potentiation of low-serum growth mediated by natural or chimeric nuclear localization signals. Molecular Biology of the Cell 10 1429-1444.

Bange J, Prechtl D, Cheburkin Y, Specht K, Harbeck N, Schmitt M, Knyazeva T, Muller S, Gartner S, Sures I, Wang H, Imyanitov E, Haring HU, Knayzev P, Iacobelli S, Hofler H \& Ullrich A 2002 Cancer progression and tumor cell motility are associated with the FGFR4 $\operatorname{Arg}(388)$ allele. Cancer Research $62840-847$.

Basilico C \& Moscatelli D 1992 The FGF family of growth factors and oncogenes. Advances in Cancer Research $\mathbf{5 9}$ $115-165$.

Basset P, Bellocq JP, Wolf C, Stoll I, Hutin P, Limacher JM, Podhajcer OL, Chenard MP, Rio MC \& Chambon P 1990 A novel metalloproteinase gene specifically expressed in stromal cells of breast carcinomas. Nature 348 699-704.

de Benedetti A \& Harris AL 1999 eIF4E expression in tumors: its possible role in progression of malignancies. International Journal of Biochemistry and Cell Biology 31 59-72.

Berger AP, Kofler K, Bektic J, Rogatsch H, Steiner H, Bartsch G \& Klocker H 2003 Increased growth factor production in a human prostatic stromal cell culture model caused by hypoxia. Prostate 57 57-65.

Burgess WH, Dionne CA, Kaplow J, Mudd R, Friesel R, Zilberstein A, Schlessinger J \& Jaye M 1990 Characterization and cDNA cloning of phospholipase C-gamma, a major substrate for heparin-binding growth factor 1 (acidic fibroblast growth factor)-activated tyrosine kinase. Molecular and Cellular Biology 10 4770-4777.

Cappellen D, De Oliveira C, Ricol D, de Medina S, Bourdin J, Sastre-Garau X, Chopin D, Thiery JP \& Radvanyi F 1999 Frequent activating mutations of FGFR3 in human bladder and cervix carcinomas. Nature Genetics 23 18-20.

Carstens RP, Eaton JV, Krigman HR, Walther PJ \& GarciaBlanco MA 1997 Alternative splicing of fibroblast growth factor receptor 2 (FGF-R2) in human prostate cancer. Oncogene 15 3059-3065.

Casci T, Vinos J \& Freeman M 1999 Sprouty, an intracellular inhibitor of Ras signaling. Cell 96 655-665.

Cassinelli G, Lanzi C, Supino R, Pratesi G, Zuco V, Laccabue D, Cuccuru G, Bombardelli E \& Zunino F 2002 Cellular bases of the antitumor activity of the novel taxane IDN 5109 (BAY598862 ) on hormone-refractory prostate cancer. Clinical Cancer Research 8 2647-2654.
Chung LW, Gleave ME, Hsieh JT, Hong SJ \& Zhau HE 1991 Reciprocal mesenchymal-epithelial interaction affecting prostate tumour growth and hormonal responsiveness. Cancer Surveys 11 91-121.

Connolly JM \& Rose DP 1998 Angiogenesis in two human prostate cancer cell lines with differing metastatic potential when growing as solid tumors in nude mice. Journal of Urology 160 932-936.

Cronauer MV, Hittmair A, Eder IE, Hobisch A, Culig Z, Ramoner R, Zhang J, Bartsch G, Reissigl A, Radmayr C, Thurnher M \& Klocker H 1997 Basic fibroblast growth factor levels in cancer cells and in sera of patients suffering from proliferative disorders of the prostate. Prostate 31 223-233.

Cronauer MV, Schulz WA, Seifert HH, Ackermann R \& Burchardt M 2003 Fibroblast growth factors and their receptors in urological cancers: basic research and clinical implications. European Urology 43 309-319.

Culig Z, Hobisch A, Cronauer MV, Radmayr C, Trapman J, Hittmair A, Bartsch G \& Klocker H 1994 Androgen receptor activation in prostatic tumor cell lines by insulin-like growth factor-I, keratinocyte growth factor, and epidermal growth factor. Cancer Research 54 5474-5478.

Davol PA \& Frackelton AR Jr 1999 Targeting human prostatic carcinoma through basic fibroblast growth factor receptors in an animal model: characterizing and circumventing mechanisms of tumor resistance. Prostate 40 178-191.

Debes JD, Sebo TJ, Lohse CM, Murphy LM, Haugen de AL \& Tindall DJ 2003 p300 in prostate cancer proliferation and progression. Cancer Research 63 7638-7640.

Demiroglu A, Steer EJ, Heath C, Taylor K, Bentley M, Allen SL, Koduru P, Brody JP, Hawson G, Rodwell R, Doody ML, Carnicero F, Reiter A, Goldman JM, Melo JV \& Cross NC 2001 The $\mathrm{t}(8 ; 22)$ in chronic myeloid leukemia fuses BCR to FGFR1: transforming activity and specific inhibition of FGFR1 fusion proteins. Blood 98 3778-3783.

Deo DD, Axelrad TW, Robert EG, Marcheselli V, Bazan NG \& Hunt JD 2002 Phosphorylation of STAT-3 in response to basic fibroblast growth factor occurs through a mechanism involving platelet-activating factor, JAK-2, and Src in human umbilical vein endothelial cells. Evidence for a dual kinase mechanism. Journal of Biological Chemistry 277 21237-21245.

Dikic I \& Giordano S 2003 Negative receptor signaling. Current Opinion in Cell Biology 15 128-135.

Dimitroff CJ, Klohs W, Sharma A, Pera P, Driscoll D, Veith J, Steinkampf R, Schroeder M, Klutchko S, Sumlin A, Henderson B, Dougherty TJ \& Bernacki RJ 1999 Antiangiogenic activity of selected receptor tyrosine kinase inhibitors, PD166285 and PD173074: implications for combination treatment with photodynamic therapy. Investigational New Drugs 17 121-135.

Doll JA, Reiher FK, Crawford SE, Pins MR, Campbell SC \& Bouck NP 2001 Thrombospondin-1, vascular endothelial growth factor and fibroblast growth factor-2 are key functional regulators of angiogenesis in the prostate. Prostate 49 293-305.

Dorkin TJ, Robinson MC, Marsh C, Neal DE \& Leung HY $1999 a$ aFGF immunoreactivity in prostate cancer and its colocalization with bFGF and FGF8. Journal of Pathology 189 $564-569$. 
Dorkin TJ, Robinson MC, Marsh C, Bjartell A, Neal DE \& Leung HY 1999b FGF8 over-expression in prostate cancer is associated with decreased patient survival and persists in androgen independent disease. Oncogene 18 2755-2761.

Dow JK \& deVere White RW 2000 Fibroblast growth factor 2: its structure and property, paracrine function, tumor angiogenesis, and prostate-related mitogenic and oncogenic functions. Urology $55800-806$.

Edwards J, Krishna NS, Witton CJ \& Bartlett JM 2003 Gene amplifications associated with the development of hormone-resistant prostate cancer. Clinical Cancer Research 9 5271-5281.

Eliceiri BP, Klemke R, Stromblad S \& Cheresh DA 1998 Integrin alpha $\mathrm{v}$ beta 3 requirement for sustained mitogen-activated protein kinase activity during angiogenesis. Journal of Cell Biology 140 1255-1263.

Erez N, Zamir E, Gour BJ, Blaschuk OW \& Geiger B 2004 Induction of apoptosis in cultured endothelial cells by a cadherin antagonist peptide: involvement of fibroblast growth factor receptor-mediated signaling. Experimental Cell Research 294 366-378.

Feng S, Wang F, Matsubara A, Kan M \& McKeehan WL 1997 Fibroblast growth factor receptor 2 limits and receptor 1 accelerates tumorigenicity of prostate epithelial cells. Cancer Research 57 5369-5378.

Folkman J \& Shing Y 1992 Angiogenesis. Journal of Biological Chemistry 267 10931-10934.

Foster BA, Kaplan PJ \& Greenberg NM 1999 Characterization of the FGF axis and identification of a novel FGFR1iiic isoform during prostate cancer progression in the TRAMP model. Prostate Cancer and Prostatic Disease 2 76-82.

Foster BA, Evangelou A, Gingrich JR, Kaplan PJ, DeMayo F \& Greenberg NM 2002 Enforced expression of FGF-7 promotes epithelial hyperplasia whereas a dominant negative FGFR2iiib promotes the emergence of neuroendocrine phenotype in prostate glands of transgenic mice. Differentiation 70 624-632.

Fox JC \& Shanley JR 1996 Antisense inhibition of basic fibroblast growth factor induces apoptosis in vascular smooth muscle cells. Journal of Biological Chemistry 271 12578-12584.

Freeman KW, Welm BE, Gangula RD, Rosen JM, Ittmann M, Greenberg NM \& Spencer DM 2003a Inducible prostate intraepithelial neoplasia with reversible hyperplasia in conditional FGFR1-expressing mice. Cancer Research 63 8256-8263.

Freeman KW, Gangula RD, Welm BE, Ozen M, Foster BA, Rosen JM, Ittmann M, Greenberg NM \& Spencer DM $2003 b$ Conditional activation of fibroblast growth factor receptor (FGFR) 1, but not FGFR2, in prostate cancer cells leads to increased osteopontin induction, extracellular signalregulated kinase activation, and in vivo proliferation. Cancer Research 63 6237-6243.

Fujiwara K, Date I, Shingo T, Yoshida H, Kobayashi K, Takeuchi A, Yang A, Tamiya T \& Ohmoto T 2003 Reduction of infarct volume and apoptosis by grafting of encapsulated basic fibroblast growth factor-secreting cells in a model of middle cerebral artery occlusion in rats. Journal of Neurosurgery 99 1053-1062.
Ghosh AK, Shankar DB, Shackleford GM, Wu K, T'Ang A, Miller GJ, Zheng J \& Roy-Burman P 1996 Molecular cloning and characterization of human FGF8 alternative messenger RNA forms. Cell Growth and Differentiation 7 1425-1434.

Giri D \& Ittmann M 2000 IL- $1 \alpha$ is a paracrine inducer of FGF-7, a key epithelial growth factor in benign prostatic hyperplasia. American Journal of Pathology 157 249-255.

Giri D \& Ittmann M 2001 Interleukin-8 is a paracrine inducer of fibroblast growth factor 2, a stromal and epithelial growth factor in benign prostatic hyperplasia. American Journal of Pathology 159 139-147.

Giri D, Ropiquet F \& Ittmann M 1999a Alterations in expression of basic fibroblast growth factor (FGF) 2 and its receptor FGFR-1 in human prostate cancer. Clinical Cancer Research 5 1063-1071.

Giri D, Ropiquet F \& Ittmann M 1999b FGF9 is an autocrine and paracrine prostatic growth factor expressed by prostatic stromal cells. Journal of Cellular Physiology 180 53-60.

Gnanapragasam VJ, Robinson MC, Marsh C, Robson CN, Hamdy FC \& Leung HY 2003 FGF8 isoform b expression in human prostate cancer. British Journal of Cancer $\mathbf{8 8}$ $1432-1438$

Grand EK, Chase AJ, Heath C, Rahemtulla A \& Cross NC 2004 Targeting FGFR3 in multiple myeloma: inhibition of t(4;14)-positive cells by SU5402 and PD173074. Leukemia 18 962-966.

Greene GF, Kitadai Y, Pettaway CA, von Eschenbach AC, Bucana CD \& Fidler IJ 1997 Correlation of metastasis-related gene expression with metastatic potential in human prostate carcinoma cells implanted in nude mice using an in situ messenger RNA hybridization technique. American Journal of Pathology 150 1571-1582.

Griffin RJ, Williams BW, Wild R, Cherrington JM, Park H \& Song CW 2002 Simultaneous inhibition of the receptor kinase activity of vascular endothelial, fibroblast, and platelet-derived growth factors suppresses tumor growth and enhances tumor radiation response. Cancer Research 62 1702-1706.

Hadari YR, Kouhara H, Lax I \& Schlessinger J 1998 Binding of Shp2 tyrosine phosphatase to FRS2 is essential for fibroblast growth factor-induced PC12 cell differentiation. Molecular and Cellular Biology 18 3966-3973.

Hadari YR, Gotoh N, Kouhara H, Lax I \& Schlessinger J 2001 Critical role for the docking-protein FRS2 alpha in FGF receptor-mediated signal transduction pathways. PNAS 98 $8578-8583$.

Hart KC, Robertson SC, Kanemitsu MY, Meyer AN, Tynan JA \& Donoghue DJ 2000 Transformation and Stat activation by derivatives of FGFR1, FGFR3, and FGFR4. Oncogene 19 3309-3320.

Hart KC, Robertson SC \& Donoghue DJ 2001 Identification of tyrosine residues in constitutively activated fibroblast growth factor receptor 3 involved in mitogenesis, Stat activation, and phosphatidylinositol 3-kinase activation. Molecular and Cellular Biology 12 931-942.

Hayward SW, Rosen MA \& Cunha GR 1997 Stromal-epithelial interactions in the normal and neoplastic prostate. British Journal of Urology 79 (Suppl 2) 18-26. 
He QM, Wei YQ, Tian L, Zhao X, Su JM, Yang L, Lu Y, Kan B, Lou YY, Huang MJ, Xiao F, Liu JY, Hu B, Luo F, Jiang Y, Wen YJ, Deng HX, Li J, Niu T \& Yang JL 2003 Inhibition of tumor growth with a vaccine based on xenogeneic homologous fibroblast growth factor receptor-1 in mice. Journal of Biological Chemistry 278 21831-21836.

Huang SF, Kim SJ, Lee AT, Karashima T, Bucana C, Kedar D, Sweeney P, Mian B, Fan D, Shepherd D, Fidler IJ, Dinney CP \& Killion JJ 2002 Inhibition of growth and metastasis of orthotopic human prostate cancer in athymic mice by combination therapy with pegylated interferon-alpha-2b and docetaxel. Cancer Research 62 5720-5726.

Huss WJ, Barrios RJ, Foster BA \& Greenberg NM 2003 Differential expression of specific FGF ligand and receptor isoforms during angiogenesis associated with prostate cancer progression. Prostate 54 8-16.

Ittmann M \& Mansukhani A 1997 Expression of fibroblast growth factors (FGFs) and FGF receptors in human prostate. Journal of Urology 157 351-356.

Jin C, McKeehan K, Guo W, Jauma S, Ittmann MM, Foster B, Greenberg NM, McKeehan WL \& Wang F 2003 Cooperation between ectopic FGFR1 and depression of FGFR2 in induction of prostatic intraepithelial neoplasia in the mouse prostate. Cancer Research 63 8784-8790.

Johnson DE \& Williams LT 1993 Structural and functional diversity in the FGF receptor multigene family. Advances in Cancer Research 60 1-41.

Johnston CL, Cox HC, Gomm JJ \& Coombes RC 1995 bFGF and aFGF induce membrane ruffling in breast cancer cells but not in normal breast epithelial cells: FGFR-4 involvement. Biochemical Journal 306 609-616.

Kabalin JN, Peehl DM \& Stamey TA 1989 Clonal growth of human prostatic epithelial cells is stimulated by fibroblasts. Prostate 14 251-263.

Klein RD, Maliner-Jongewaard MS, Udayakumar TS, Boyd JL, Nagle RB \& Bowden GT 1999 Promatrilysin expression is induced by fibroblast growth factors in the prostatic carcinoma cell line LNCaP but not in normal primary prostate epithelial cells. Prostate 41 215-223.

Klingenberg O, Wiedocha A, Citores L \& Olsnes S 2000 Requirement of phosphatidylinositol 3-kinase activity for translocation of exogenous aFGF to the cytosol and nucleus. Journal of Biological Chemistry 275 11972-11980.

Knox JD, Wolf C, McDaniel K, Clark V, Loriot M, Bowden GT \& Nagle RB 1996 Matrilysin expression in human prostate carcinoma. Molecular Carcinogenesis 15 57-63.

Kouhara H, Hadari YR, Spivak-Kroizman T,Schilling J,BarSagi D, Lax I \& Schlessinger J 1997 A lipid-anchored Grb2binding protein that links FGF-receptor activation to the Ras/MAPK signaling pathway. Cell 89 693-702.

Koziczak M, Holbro T \& Hynes NE 2004 Blocking of FGFR signaling inhibits breast cancer cell proliferation through downregulation of D-type cyclins. Oncogene 23 3501-3508.

Kramer S, Okabe M, Hacohen N, Krasnow MA \& Hiromi Y 1999 Sprouty: a common antagonist of FGF and EGF signaling pathways in Drosophila. Development 126 2515-2525.
Kwabi-Addo B, Ropiquet F, Giri D \& Ittmann M 2001 Alternative splicing of fibroblast growth factor receptors in human prostate cancer. Prostate 46 163-172.

Kwabi-Addo B, Wang J, Erdem H, Vaid A, Castro P, Ayala G \& Ittmann M 2004 Expression of Sprouty1, an inhibitor of fibroblast growth factor signal transduction, is decreased in human prostate cancer. Cancer Research 64 4728-4735.

Lanciotti J, Song A, Doukas J, Sosnowski B, Pierce G, Gregory R, Wadsworth S \& O'Riordan C 2003 Targeting adenoviral vectors using heterofunctional polyethylene glycol FGF2 conjugates. Molecular Therapy 8 99-107.

Leung HY, Dickson C, Robson CN \& Neal DE 1996 Overexpression of fibroblast growth factor-8 in human prostate cancer. Oncogene 12 1833-1835.

Li Z, Zhu YX, Plowright EE, Bergsagel PL, Chesi M, Patterson B, Hawley TS, Hawley RG \& Stewart AK 2001 The myeloma-associated oncogene fibroblast growth factor receptor 3 is transforming in hematopoietic cells. Blood 97 2413-2419.

Mack CF, Knox JD, Powell WC, Nagle RB \& Bowden GT 1993 Functional-role of the metalloproteinase matrilysin in human prostate-cancer. International Journal of Radiation OncologyBiology-Physics 27217.

Matrisian LM, Mcdonnell S, Miller DB, Navre M, Seftor EA \& Hendrix MJC 1991 The role of the matrix metalloproteinase stromelysin in the progression of squamous-cell carcinomas. American Journal of the Medical Sciences 302 157-162.

Matsubara A, Kan M, Feng S \& McKeehan WL 1998 Inhibition of growth of malignant rat prostate tumor cells by restoration of fibroblast growth factor receptor 2. Cancer Research $\mathbf{5 8}$ $1509-1514$.

Munro NP \& Knowles MA 2003 Fibroblast growth factors and their receptors in transitional cell carcinoma. Journal of Urology 169 675-682.

Mehta PB, Robson CN, Neal DE \& Leung HY 2000a Serum keratinocyte growth factor measurement in patients with prostate cancer. Journal of Urology 164 2151-2155.

Mehta P, Robson CN, Neal DE \& Leung HY 2000b Fibroblast growth factor receptor-2 mutation analysis in human prostate cancer. British Journal of Urology International 86 681-685.

Mohammadi M, Honegger AM, Rotin D, Fischer R, Bellot F, Li W, Dionne CA, Jaye M, Rubinstein M \& Schlessinger J 1991 A tyrosine-phosphorylated carboxy-terminal peptide of the fibroblast growth factor receptor (Flg) is a binding site for the SH2 domain of phospholipase C-gamma 1. Molecular and Cellular Biology 11 5068-5078.

Mohammadi M, McMahon G, Sun L, Tang C, Hirth P, Yeh BK, Hubbard SR \& Schlessinger J 1997 Structures of the tyrosine kinase domain of fibroblast growth factor receptor in complex with inhibitors. Science 276 955-960.

Naimi B, Latil A, Berthon P \& Cussenot O 2000 No evidence for fibroblast growth factor receptor 3 (FGFR-3) R248C/S249C mutations in human prostate cancer. International Journal of Cancer 87 455-456.

Naimi B, Latil A, Fournier G, Mangin P, Cussenot O \& Berthon P 2002 Down-regulation of (IIIb) and (IIIc) isoforms of fibroblast growth factor receptor 2 (FGFR2) is associated 
with malignant progression in human prostate. Prostate 52 245-252.

Naski MC \& Ornitz DM 1998 FGF signaling in skeletal development. Frontiers in Bioscience 3 D781-D794.

Nemeth JA, Zelner DJ, Lang S \& Lee C 1998 Keratinocyte growth factor in the rat ventral prostate: androgenindependent expression. Journal of Endocrinology 156 $115-125$.

Newell KJ, Witty JP, Rodgers WH \& Matrisian LM 1994 Expression and localization of matrix-degrading metalloproteinases during colorectal tumorigenesis. Molecular Carcinogenesis 10 199-206.

Ornitz DM \& Itoh N 2001 Fibroblast growth factors. Genome Biology 2 reviews 3005.1-3005.12.

Ornitz DM, Xu J, Colvin JS, McEwen DG, MacArthur CA, Coulier F, Gao G \& Goldfarb M 1996 Receptor specificity of the fibroblast growth factor family. Journal of Biological Chemistry 271 15292-15297.

Ortega S, Ittmann M, Tsang SH, Ehrlich M \& Basilico C 1998 Neuronal defects and delayed wound healing in mice lacking fibroblast growth factor 2. PNAS 95 5672-5677.

Ozen M, Giri D, Ropiquet F, Mansukhani A \& Ittmann M 2001 Role of fibroblast growth factor receptor signaling in prostate cancer cell survival. Journal of the National Cancer Institute $\mathbf{9 3}$ 1783-1790.

Ozen M, Medrano EE \& Ittmann M 2004 Inhibition of proliferation and survival of melanoma cells by adenoviralmediated expression of dominant negative fibroblast growth factor receptor. Melanoma Research 14 13-21.

Pajouh MS, Nagle RB, Breathnach R, Finch JS, Brawer MK \& Bowden GT 1991 Expression of metalloproteinase genes in human prostate-cancer. Journal of Cancer Research and Clinical Oncology 117 144-150.

Payson RA, Chotani MA \& Chiu IM 1998 Regulation of a promoter of the fibroblast growth factor 1 gene in prostate and breast cancer cells. Journal of Steroid Biochemistry and Molecular Biology 66 93-103.

Planz B, Wang Q, Kirley SD, Lin CW \& McDougal WS 1998 Androgen responsiveness of stromal cells of the human prostate: regulation of cell proliferation and keratinocyte growth factor by androgen. Journal of Urology $\mathbf{1 6 0}$ 1850-1855.

Planz B, Aretz HT, Wang Q, Tabatabaei S, Kirley SD, Lin CW \& McDougal WS 1999 Immunolocalization of the keratinocyte growth factor in benign and neoplastic human prostate and its relation to androgen receptor. Prostate 41 233-242.

Polnaszek N, Kwabi-Addo B, Peterson LE, Ozen M, Greenberg NM, Ortega S, Basilico C \& Ittmann M 2003 Fibroblast growth factor 2 promotes tumor progression in an autochthonous mouse model of prostate cancer. Cancer Research 63 5754-5760.

Polnaszek N, Kwabi-Addo B, Wang J \& Ittmann M 2004 FGF17 is an autocrine prostatic epithelial growth factor and is upregulated in benign prostatic hyperplasia. Prostate $\mathbf{6 0}$ $18-24$.

Powell WC, Knox JD, Navre M, Grogan TM, Kittelson J, Nagle RB \& Bowden GT 1993 Expression of the metalloproteinase matrilysin in Du-145 cells increases their invasive potential in severe combined immunodeficient mice. Cancer Research $\mathbf{5 3}$ 417-422.

Powers CJ, McLeskey SW \& Wellstein A 2000 Fibroblast growth factors, their receptors and signaling. Endocrine-Related Cancer 7 165-197.

Raffioni S, Thomas D, Foehr ED, Thompson LM \& Bradshaw RA 1999 Comparison of the intracellular signaling responses by three chimeric fibroblast growth factor receptors in PC12 cells. PNAS 96 7178-7183.

Reich A, Sapir A \& Shilo BZ 1999 Sprouty is a general inhibitor of receptor tyrosine kinase signaling. Development $\mathbf{1 2 6}$ 4139-4147.

Ropiquet F, Huguenin S, Villette JM, Ronfle V, Le Brun G, Maitland NJ, Cussenot O, Fiet J \& Berthon P 1999a FGF7/ KGF triggers cell transformation and invasion on immortalised human prostatic epithelial PNT1A cells. International Journal of Cancer 82 237-243.

Ropiquet F, Giri D, Lamb DJ \& Ittmann M $1999 b$ FGF7 and FGF2 are increased in benign prostatic hyperplasia and are associated with increased proliferation. Journal of Urology $162595-599$.

Ropiquet F, Giri D, Kwabi-Addo B, Schmidt K \& Ittmann M $2000 a$ FGF-10 is expressed at low levels in the human prostate. Prostate 44 334-338.

Ropiquet F, Giri D, Kwabi-Addo B, Mansukhani A \& Ittmann M $2000 b$ Increased expression of fibroblast growth factor 6 in human prostatic intraepithelial neoplasia and prostate cancer. Cancer Research 60 4245-4250.

Roumiantsev S, Krause DS, Neumann CA, Dimitri CA, Asiedu F, Cross NC \& Van Etten RA 2004 Distinct stem cell myeloproliferative/T lymphoma syndromes induced by ZNF198-FGFR1 and BCR-FGFR1 fusion genes from 8p11 translocations. Cancer Cell 5 287-298.

Rowan BG, Weigel NL \& O'Malley BW 2000 Phosphorylation of steroid receptor coactivator-1. Identification of the phosphorylation sites and phosphorylation through the mitogen-activated protein kinase pathway. Journal of Biological Chemistry 275 4475-4483.

Rudra-Ganguly N, Zheng J, Hoang A \& Roy-Burman P 1998 Downregulation of human FGF8 activity by antisense constructs in murine fibroblastic and human prostatic carcinoma cell systems. Oncogene 16 1487-1492.

Schafer T, Zentgraf H, Zehe C, Brugger B, Bernhagen J \& Nickel W 2004 Unconventional secretion of fibroblast growth factor 2 is mediated by direct translocation across the plasma membrane of mammalian cells. Journal of Biological Chemistry 279 6244-6251.

Schoorlemmer J \& Goldfarb M 2001 Fibroblast growth factor homologous factors are intracellular signaling proteins. Current Biology 11 793-797.

Shaoul E, Reich-Slotky R, Berman B \& Ron D 1995 Fibroblast growth factor receptors display both common and distinct signaling pathways. Oncogene 10 1553-1561.

Sibley K, Stern P \& Knowles MA 2001 Frequency of fibroblast growth factor receptor 3 mutations in sporadic tumours. Oncogene 20 4416-4418.

Sidenius N \& Blasi F 2003 The urokinase plasminogen activator system in cancer: recent advances and implication 
for prognosis and therapy. Cancer Metastasis Reviews 22 205-222.

Song Z, Powell WC, Kasahara N, van Bokhoven A, Miller GJ \& Roy-Burman P 2000a The effect of fibroblast growth factor 8, isoform b, on the biology of prostate carcinoma cells and their interaction with stromal cells. Cancer Research 60 6730-6736.

Song S, Wientjes MG, Gan Y \& Au JL 2000b Fibroblast growth factors: an epigenetic mechanism of broad spectrum resistance to anticancer drugs. PNAS $978658-8663$.

Song Z, Wu X, Powell WC, Cardiff RD, Cohen MB, Tin RT, Matusik RJ, Miller GJ \& Roy-Burman P 2002 Fibroblast growth factor 8 isoform $\mathrm{B}$ overexpression in prostate epithelium: a new mouse model for prostatic intraepithelial neoplasia. Cancer Research 62 5096-5105.

Stadler WM, Cao D, Vogelzang NJ, Ryan CW, Hoving K, Wright R, Karrison T \& Vokes EE 2004 A randomized phase II trial of the antiangiogenic agent SU5416 in hormonerefractory prostate cancer. Clinical Cancer Research $\mathbf{1 0}$ 3365-3370.

Sugamoto T, Tanji N, Sato K, Fujita H, Nishio S, Sakanaka M \& Yokoyama M 2001 The expression of basic fibroblast growth factor and vascular endothelial growth factor in prostatic adenocarcinoma: correlation with neovascularization. Anticancer Research 21 77-88.

Takahashi H 1998 Studies on the expression of fibroblast growth factors and fibroblast growth factor receptors in human prostate cancer. Nippon Hinyokika Gakkai Zasshi 89 836-845.

Tanaka A, Furuya A, Yamasaki M, Hanai N, Kuriki K, Kamiakito T, Kobayashi Y, Yoshida H, Koike M \& Fukayama M 1998 High frequency of fibroblast growth factor (FGF) 8 expression in clinical prostate cancers and breast tissues, immunohistochemically demonstrated by a newly established neutralizing monoclonal antibody against FGF 8. Cancer Research 58 2053-2056.

Tashiro E, Maruki H, Minato Y, Doki Y, Weinstein IB \& Imoto M 2003 Overexpression of cyclin D1 contributes to malignancy by up-regulation of fibroblast growth factor receptor 1 via the $\mathrm{pRB} / \mathrm{E} 2 \mathrm{~F}$ pathway. Cancer Research $6 \mathbf{3}$ $424-431$

Taverna S, Ghersi G, Ginestra A, Rigogliuso S, Pecorella S, Alaimo G, Saladino F, Dolo V, Dell'Era P, Pavan A, Pizzolanti G, Mignatti P, Presta M \& Vittorelli ML 2003 Shedding of membrane vesicles mediates fibroblast growth factor-2 release from cells. Journal of Biological Chemistry 278 51911-51919.

Tefft JD, Lee M, Smith S, Leinwand M, Zhao JS, Bringas P, Crowe DL \& Warburton D 1999 Conserved function of mSpry-2, a murine homolog of Drosophila sprouty, which negatively modulates respiratory organogenesis. Current Biology 9 219-222.

Udayakumar TS, Stratton MS, Nagle RB \& Bowden GT 2002 Fibroblast growth factor-1 induced promatrilysin expression through the activation of extracellular-regulated kinases and STAT3. Neoplasia 4 60-67.

Udayakumar TS, Bair EL, Nagle RB \& Bowden GT 2003 Pharmacological inhibition of FGF receptor signaling inhibits
LNCaP prostate tumor growth, promatrilysin, and PSA expression. Molecular Carcinogenesis 38 70-77.

Valve EM, Nevalainen MT, Nurmi MJ, Laato MK, Martikainen PM \& Harkonen PL 2001 Increased expression of FGF-8 isoforms and FGF receptors in human premalignant prostatic intraepithelial neoplasia lesions and prostate cancer. Laboratory Investigation 81 815-826.

Wang F, McKeehan K,Yu C \& McKeehan WL 2002 Fibroblast growth factor receptor 1 phosphotyrosine 766 : molecular target for prevention of progression of prostate tumors to malignancy. Cancer Research 62 1898-1903.

Wang F, McKeehan K, Yu C, Ittmann M \& McKeehan WL $2004 a$ Chronic activity of ectopic type 1 fibroblast growth factor receptor tyrosine kinase in prostate epithelium results in hyperplasia accompanied by intraepithelial neoplasia. Prostate 58 1-12.

Wang J, Stockton D \& Ittmann M $2004 b$ The FGFR-4 Arg ${ }^{388}$ allele is associated with prostate cancer initiation and progression. Clinical Cancer Research 10 6169-6178.

West AF, O'Donnell M, Charlton RG, Neal DE \& Leung HY 2001 Correlation of vascular endothelial growth factor expression with fibroblast growth factor- 8 expression and clinico-pathologic parameters in human prostate cancer. British Journal of Cancer 85 576-583.

Wilson CL \& Matrisian LM 1996 Matrilysin: an epithelial matrix metalloproteinase with potentially novel functions. International Journal of Biochemistry and Cell Biology 28 123-136.

Wong A, Lamothe B, Lee A, Schlessinger J, Lax I \& Li A 2002 FRS2 alpha attenuates FGF receptor signaling by Grb2mediated recruitment of the ubiquitin ligase Cbl. PNAS 99 6684-6689.

Xiao S, Nalabolu SR, Aster JC, Ma J, Abruzzo L, Jaffe ES, Stone R, Weissman SM, Hudson TJ \& Fletcher JA 1998 FGFR1 is fused with a novel zinc-finger gene, ZNF198, in the $\mathrm{t}(8 ; 13)$ leukaemia/lymphoma syndrome. Nature Genetics $\mathbf{1 8}$ 84-87.

Yan G, Fukabori Y, Nikolaropoulos S, Wang F \& McKeehan WL 1992 Heparin-binding keratinocyte growth factor is a candidate stromal-to-epithelial-cell andromedin. Molecular Endocrinology 6 2123-2128.

Yan G, Fukabori Y, McBride G, Nikolaropolous S \& McKeehan WL 1993. Exon switching and activation of stromal and embryonic fibroblast growth factor (FGF)-FGF receptor genes in prostate epithelial cells accompany stromal independence and malignancy. Molecular and Cellular Biology 13 4513-4522.

Zellweger T, Ninck C, Mirlacher M, Annefeld M, Glass AG, Gasser TC, Mihatsch MJ, Gelmann EP \& Bubendorf L 2003 Tissue microarray analysis reveals prognostic significance of syndecan-1 expression in prostate cancer. Prostate 55 20-29.

Zhang YL, Song SH, Yang F, Au JLS \& Wientjes MG 2001 Nontoxic doses of suramin enhance activity of doxorubicin in prostate tumors. Journal of Pharmacology and Experimental Therapeutics 299 426-433. 